\title{
Progesterone Receptor Status 3+
}

National Cancer Institute

\section{Source}

National Cancer Institute. Progesterone Receptor Status 3+. NCI Thesaurus. Code C147859.

An immunohistochemical result of 3 for progesterone receptor expression that is considered positive for expression. 